\title{
man \\ Study of Internal Drainage Systems for Steel Bridge Deck Pavements
}

\author{
Wen Nie ${ }^{1,2, *(1)}$, Duanyi Wang ${ }^{1}$, Jian Huang ${ }^{3}$, Caifeng Jiang ${ }^{1, *}$ and Junjian Yan ${ }^{1,2}$ \\ 1 School of Civil Engineering and Transportation, South China University of Technology, Wushan Road, \\ Tianhe District, Guangzhou 510641, China; tcdywang@scut.edu.cn (D.W.); junjianyan@outlook.com (J.Y.) \\ 2 Guangzhou Xiaoning Roadway Engineering Technology Research Institute Co., Ltd., Wushan Road, \\ Tianhe District, Guangzhou 510641, China \\ 3 Guangdong Nanyue Transportation Investment \& Construction Co., Ltd., Baiyun Road, Yuexiu District, \\ Guangzhou 510199, China; 15113717120@163.com \\ * Correspondence: 202010101505@mail.scut.edu.cn (W.N.); veephone23@gmail.com (C.J.);
}

check for updates

Citation: Nie, W.; Wang, D.; Huang, J.; Jiang, C.; Yan, J. Study of Internal Drainage Systems for Steel Bridge Deck Pavements. Buildings 2022, 12, 284. https://doi.org/ 10.3390 /buildings12030284

Academic Editors: Xiaopei Cai,

Huayang Yu and Tao Wang

Received: 12 January 2022

Accepted: 21 February 2022

Published: 2 March 2022

Publisher's Note: MDPI stays neutral with regard to jurisdictional claims in published maps and institutional affiliations.

Copyright: (C) 2022 by the authors. Licensee MDPI, Basel, Switzerland. This article is an open access article distributed under the terms and conditions of the Creative Commons Attribution (CC BY) license (https:// creativecommons.org/licenses/by/ $4.0 /)$

\begin{abstract}
As large span steel bridges develop rapidly, the type of steel deck paving is also diversifying However, the current steel deck paving layer is a dense-graded mixture of both upper and lower layers. This makes it difficult for water to drain out of the dense deck when it enters the interior of the deck, and the deck is easily damaged by the traffic load. This paper aims to prolong the service life of the pavement and solve the problem that the pavement is prone to water damage under the existing pavement system. In this paper, a new steel bridge deck paving system is formed by developing a new type of waterproofing binder layer material and developing an open-graded paving layer underlayment. Through indoor tests and finite element software analysis, the effect of the environment on the pull-out strength of the waterproofing binder layer material under different permaculture conditions is investigated; a suitable void ratio control range for the paving layer is explored through paving layer seepage analysis and indoor tests. The study revealed that the new epoxy resin waterproofing bonding layer was able to maintain a large pull-out strength value in a $60{ }^{\circ} \mathrm{C}$ water bath for 2 weeks. The paving with void ratios of 18,20 , and $22 \%$ were all able to drain $50 \%$ of the water inside the paving within $2 \mathrm{~h}$, with excellent drainage capacity. Based on the modeling analysis and indoor test results, the target void ratio of the asphalt mix under the pavement is recommended to be controlled at $20-22 \%$, with a void ratio in this range to solve the problem of water entering the steel bridge deck pavement and causing pavement distress.
\end{abstract}

Keywords: steel bridge decks; epoxy resins; tensile strength; seepage analysis; void ratio

\section{Introduction}

In comparison with Germany, the United States, Japan, and other countries, the steel bridge deck technology research in China started late [1,2]. Due to the special climatic environment and traffic load in China, the steel bridge decks built in the early stages with foreign experience have all suffered from early damage to varying degrees, and the steel deck paving problem is particularly prominent, resulting in a serious impact on society and the economy $[3,4]$. The materials often used for steel bridge deck paving at this stage are asphalt marshmallow SMA, poured asphalt mixes GA, MA, and epoxy asphalt mixes EA and FAC [5-7]. Typical steel bridge deck pavement structural solutions and applications in China are shown in Table 1 [8-14]. Due to its special material and the environment in which it is located, steel bridge decks have very high requirements for water and rust resistance $[15,16]$. To eliminate direct contact between the steel bridge deck and water when designing the steel deck pavement, the mix grading design requires that the water penetration coefficient should reach no water penetration $[17,18]$. However, during the actual construction and subsequent opening to traffic, it is difficult to ensure that the steel bridge deck paving layer is completely watertight due to construction uniformity, joints, 
and bridge deck paving cracking. The water inside the paving layer cannot be drained away quickly, and the water that accumulates inside the paving layer will directly react with the steel bridge deck in a redox reaction. This leads to rust and corrosion of the steel bridge panels, which in turn affects the bond strength between the paving layers and leads to delamination of the steel bridge deck paving layers [19-21]. Furthermore, under the action of traffic loads, this can lead to the pavement being pushed and cracked, as shown in Figure 1 which greatly shortens the service life of the steel deck pavement [22-26].

Table 1. Typical steel deck pavement structure options.

\begin{tabular}{|c|c|c|c|c|c|c|c|}
\hline Paving Solution & $\mathbf{A}$ & B & $\mathrm{C}$ & $\mathbf{D}$ & E & $\mathbf{F}$ & G \\
\hline Upper layer & SMA & EA & SMA & \multirow{2}{*}{ GA } & SMA & EA & SMA \\
\hline Lower layer & SMA & EA & GA & & EA & GA & UHPC \\
\hline $\begin{array}{c}\text { Start of } \\
\text { application (years) }\end{array}$ & 1997 & 2000 & 1997 & 2012 & 2004 & 1998 & 2011 \\
\hline Bridge name & $\begin{array}{l}\text { Humen } \\
\text { Bridge }\end{array}$ & $\begin{array}{c}\text { Nanjing } \\
\text { Second Bridge }\end{array}$ & $\begin{array}{c}\text { Swedish } \\
\text { Marina } \\
\text { High Bridge }\end{array}$ & $\begin{array}{c}\text { Bosporus } \\
\text { Second Bridge }\end{array}$ & $\begin{array}{l}\text { Xiling Yangtze } \\
\text { River Bridge }\end{array}$ & $\begin{array}{l}\text { Akashi Kaikyo } \\
\text { Bridge, Japan }\end{array}$ & Mafang Bridge \\
\hline Main failure types & $\begin{array}{l}\text { Crack, de- } \\
\text { lamination }\end{array}$ & $\begin{array}{l}\text { Delamination, } \\
\text { bulge, crack }\end{array}$ & Ruts, cracks & Ruts, cracks & $\begin{array}{l}\text { Delamination, } \\
\text { cracks }\end{array}$ & Ruts, cracks & Ruts, cracks \\
\hline
\end{tabular}

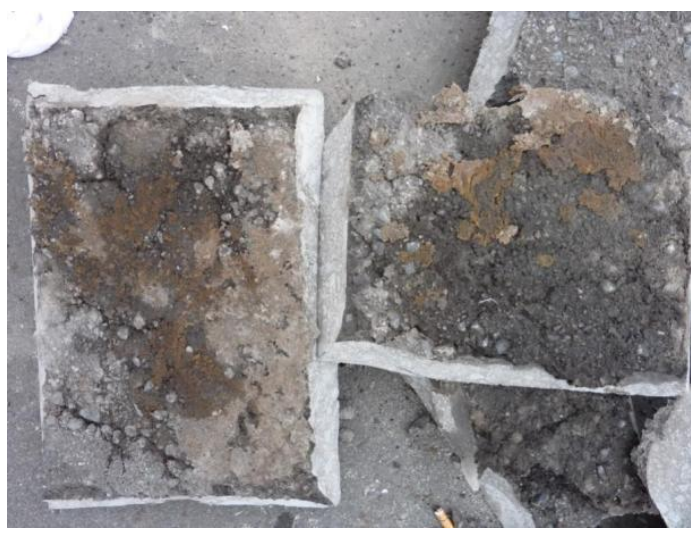

(a)

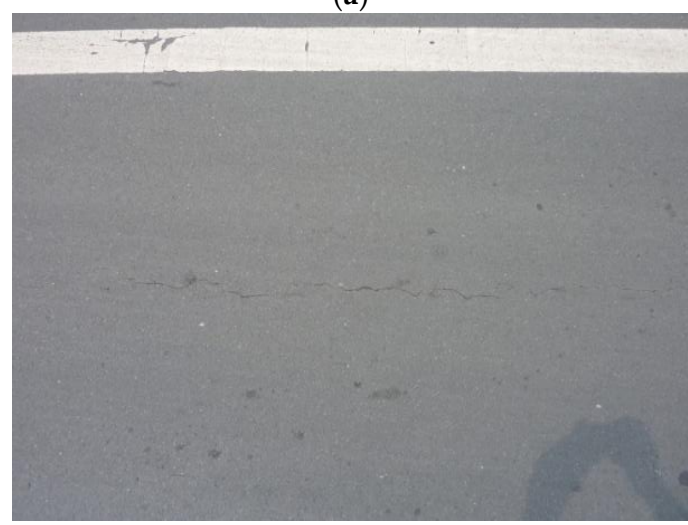

(c)

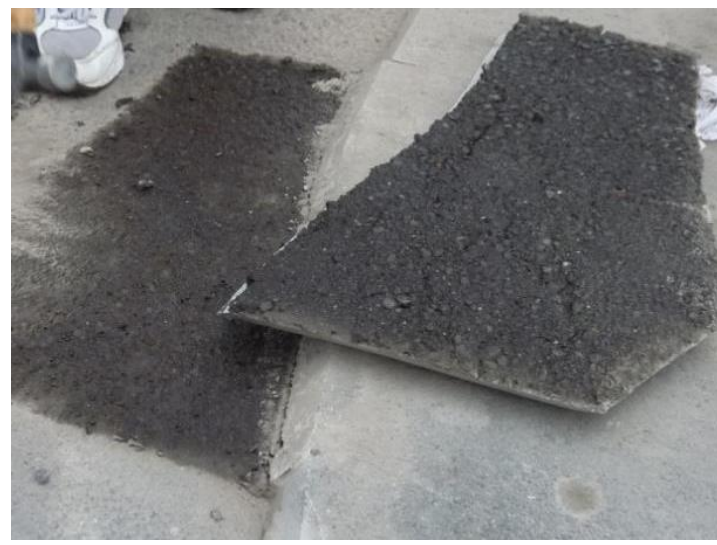

(b)

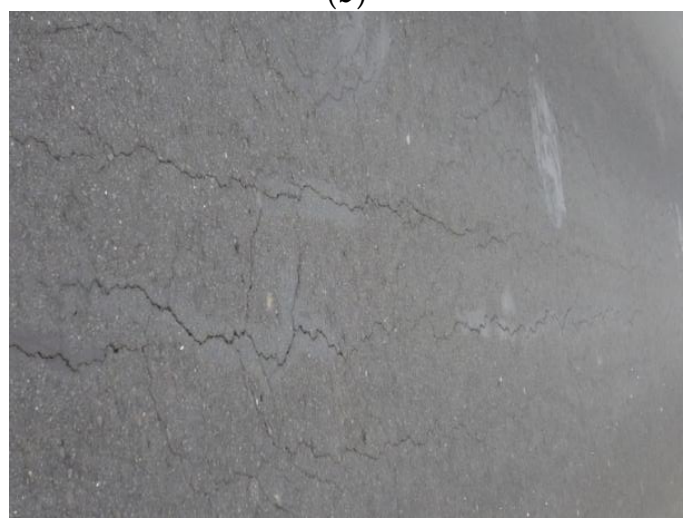

(d)

Figure 1. Delamination and cracking of the paving layer: (a) Early stage of longitudinal cracking of epoxy asphalt paving; (b) Longitudinal cracking and web cracking of epoxy asphalt paving; (c) Condition of binder layer for paving delamination cracking; (d) Damp condition of binder layer for paving delamination and cracking.

Olard et al., developed a five-point bending fatigue test for the performance design of wear layer of orthotropic steel bridge, and improved the service life of pavement layer 
through the performance design of mixture [27]; Wang et al., established a three-parameter fatigue equation model using the finite element mechanics method and four-point bending fatigue test and proposed to use the fatigue limit as the control parameter in the design of epoxy asphalt concrete. The performance of the mixture was improved through mechanical analysis and fatigue test, to improve the test life of the pavement layer [23]; Using a three-dimensional finite element model, Tae et al., evaluated the effect of pavement design parameters on the performance of four pavement systems which showed that a better bonding interface between the steel bridge deck and pavement can make the pavement resistant to the fatigue limit [28]. The above research is based on the existing pavement system, and the service life of the pavement is extended through the mechanical analysis of the pavement, the improvement of the performance of the mixture, and the improvement of the adhesive layer. However, the above research has not fundamentally solved the problem of water damage in the pavement. However, due to the current stage of paving materials, a dense-graded mix, when the water comes through the large pore position, causing joints, cracks and other problems into the steel bridge deck layer inside, the water cannot be drained in a timely manner, and in the role of traffic load, will aggravate the development of paving layer disease. To prolong the service life of the pavement layer and solve the problem that the pavement layer is prone to water damage under the existing pavement system, this paper draws on the concept of human management of flooding, using a combination of blocking and sparing a new steel bridge deck paving system, that is, the upper layer of the steel bridge deck paving using dense-graded epoxy asphalt mixture, the lower layer of the paving using open-graded asphalt mixture, while the steel bridge deck rust-proof waterproof treatment. In this paper, indoor simulated epoxy binder layer soak tests were conducted to investigate the decay rate of bond strength and acceptable soak time of the epoxy binder layer under the most adverse environmental conditions. Then, the seepage analysis software was used to set different void ratios to investigate the suitable void ratio control range for asphalt mixes for drainage pavements, and its reasonableness was verified by water infiltration tests and $60{ }^{\circ} \mathrm{C}$ dynamic stability tests. At the same time, we also verified the reliability of the performance of the drained epoxy asphalt mixes through the mix ratio design.

\section{Experiment on the Effect of Water Immersion on Epoxy Resin Bonded Layers}

To study the impact of water into the interior of the paving layer on the epoxy resin waterproofing bonding layer, we selected different types of waterproofing bonding layer materials for indoor water soaking resistance test research. As the steel bridge deck is generally in a natural environment such as a large river and sea, environmental humidity, and the environment contains a large amount of water salt, very easy to produce erosion of the steel bridge panel, and the temperature of the steel bridge panel after exposure to the sun is high, therefore, we use room temperature water bath, room temperature salt bath, $60{ }^{\circ} \mathrm{C}$ water bath three kinds of environment in the indoor test for steel plate immersion simulation test.

\subsection{Waterproofing Bonding Layer Materials}

In this paper, we select the waterproof viscous layer oil A, B component materials. Component A, B material test results are shown in Tables 2 and 3, where component $\mathrm{A}$ is divided into high viscosity component $A_{1}$ and low viscosity component $A_{2}$, component $B$ is divided into low viscosity component $B_{1}, B_{2}$, and high viscosity component $B_{3}$.

There are six possibilities for mixing the $\mathrm{AB}$ component of the waterproofing bonding layer: $A_{1} B_{1}, A_{1} B_{2}, A_{1} B_{3}, A_{2} B_{1}, A_{2} B_{2}, A_{2} B_{3}$. The epoxy mixing composition table is shown in Table 4 below. 
Table 2. Epoxy resin A component test results.

\begin{tabular}{cccc}
\hline Physical Properties & Specifications & $\mathbf{A}_{\mathbf{1}}$ & $\mathbf{A}_{\mathbf{2}}$ \\
\hline Viscosity $\left(23^{\circ} \mathrm{C},[\mathrm{P}]\right)$ & $1000 \sim 5000$ & 4892 & 1860 \\
\hline Epoxide equivalent & $190 \sim 220$ & 197 & 200 \\
\hline Specific weight $\left(23^{\circ} \mathrm{C}\right)$ & $1.0 \sim 1.2$ & 1.15 & 1.05 \\
\hline Flash point $\left({ }^{\circ} \mathrm{C}\right)$ & $>220$ & 245 & 244 \\
\hline
\end{tabular}

Table 3. Test results of component B of epoxy resin.

\begin{tabular}{ccccc}
\hline Physical Properties & Specifications & $\mathbf{B}_{\mathbf{1}}$ & $\mathbf{B}_{\mathbf{2}}$ & $\mathbf{B}_{\mathbf{3}}$ \\
\hline Viscosity $\left(23^{\circ} \mathrm{C},[\mathrm{P}]\right)$ & $100 \sim 800$ & 1753 & 1643 & 4762 \\
\hline Specific weight $\left(23^{\circ} \mathrm{C}\right)$ & $0.8 \sim 1.0$ & 0.85 & 0.86 & 0.91 \\
\hline Acid value $(\mathrm{mg}, \mathrm{KOH} / \mathrm{g})$ & $150 \sim 200$ & 157 & 163 & 162 \\
\hline Flash point $\left({ }^{\circ} \mathrm{C}\right)$ & $>145$ & 172 & 170 & 186 \\
\hline
\end{tabular}

Table 4. Oil components of the epoxy waterproof adhesive layer.

\begin{tabular}{cccc}
\hline \multirow{2}{*}{ Composition No. } & \multicolumn{3}{c}{ Combinations } \\
\cline { 2 - 4 } & Composition A & Composition B \\
\hline 1 & $\mathrm{~A}_{1}$ & $\mathrm{~B}_{1}$ \\
\hline 2 & $\mathrm{~A}_{1}$ & $\mathrm{~B}_{3}$ \\
\hline 3 & $\mathrm{~A}_{1}$ & $\mathrm{~B}_{1}$ \\
\hline 4 & $\mathrm{~A}_{2}$ & $\mathrm{~B}_{2}$ \\
\hline 5 & $\mathrm{~A}_{2}$ & $\mathrm{~B}_{3}$ \\
\hline 6 & $\mathrm{~A}_{2}$ & \\
\hline
\end{tabular}

2.2. Laboratory Simulation Test

(1) In this experiment, $30 \times 30 \mathrm{~cm}^{2}$ steel plates were used and polished using a grinding machine with a roughness control of $100 \sim 120 \mu \mathrm{m}$ and cleanliness greater than Sa3.0 grade, for a total of 12 pieces, as shown in Figure 2.

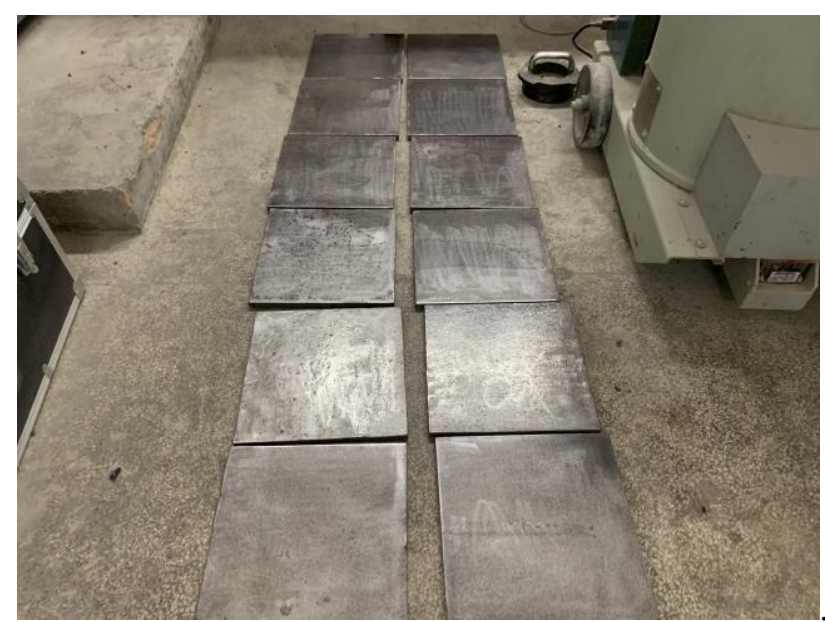

Figure 2. Steel plate after grinding. 
(2) Each steel plate is separated into 6 areas using transparent tape, each area being the same size, as in Figure 3.

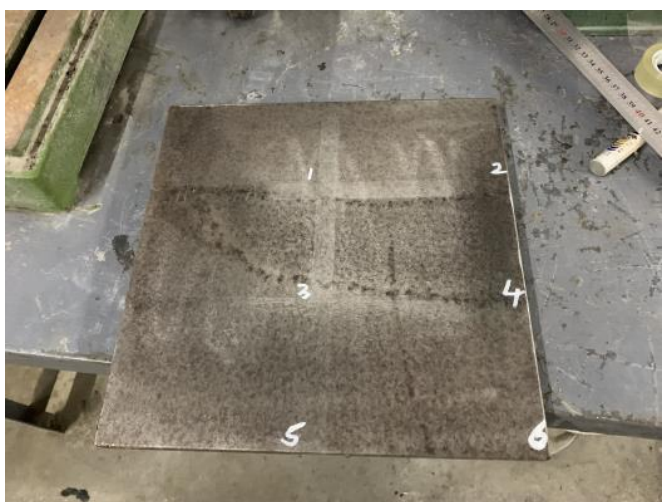

(a)

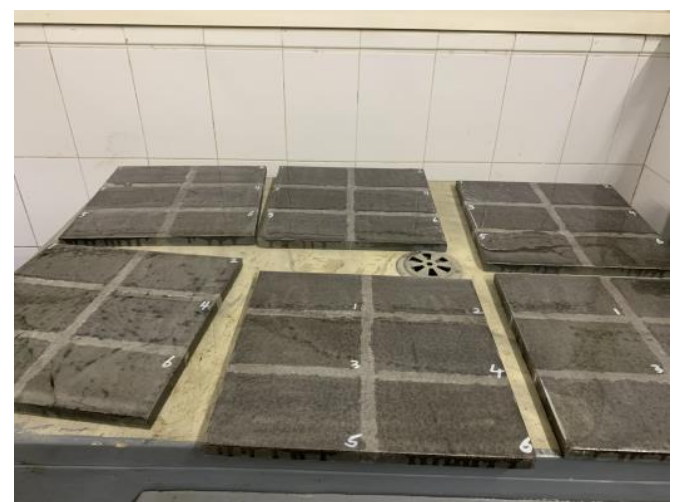

(b)

Figure 3. Steel plate area division: (a) Division of steel plates; (b) Coating different combinations of epoxy resin in different regions.

(3) The mixing and application were carried out following the mixing requirements provided by the material supplier, with an application volume of $0.4 \mathrm{~kg} / \mathrm{m}^{2}$ epoxy forming requirements as shown in Table 5 below.

Table 5. Table of requirements for the use of epoxy resin components.

\begin{tabular}{ccccc}
\hline Composition A & Percentage of Use & Sample Weight & Operation Time $/ \mathbf{2 5}{ }^{\circ} \mathbf{C}, \mathbf{1 5} \mathbf{g}$ & Curing Time $/ 25{ }^{\circ} \mathbf{C}, \mathbf{1 5} \mathbf{g}$ \\
\hline $\mathrm{A}_{1}$ & - & $5 \mathrm{~kg}$ & & \\
\hline $\mathrm{A}_{2}$ & - & $5 \mathrm{~kg}$ & & $2 \mathrm{~h}$ \\
\hline Composition B & $3: 1$ & & $30 \mathrm{~min}$ & $2 \mathrm{~h}$ \\
\hline $\mathrm{B}_{1}$ & $3: 1$ & $0.9 \mathrm{~kg}$ & $30 \mathrm{~min}$ & $4 \mathrm{~h}$ \\
\hline $\mathrm{B}_{2}$ & $2: 1$ & $1 \mathrm{~kg}$ & $40 \mathrm{~min}$ & \\
\hline $\mathrm{B}_{3}$ & & $1 \mathrm{~kg}$ & & \\
\hline
\end{tabular}

(4) Maintenance conditions: selection of conditions (room temperature water bath, $60{ }^{\circ} \mathrm{C}$ water bath, room temperature saltwater bath), maintenance time (1 week, 2 weeks, 4 weeks, 8 weeks), as in Figure 4.

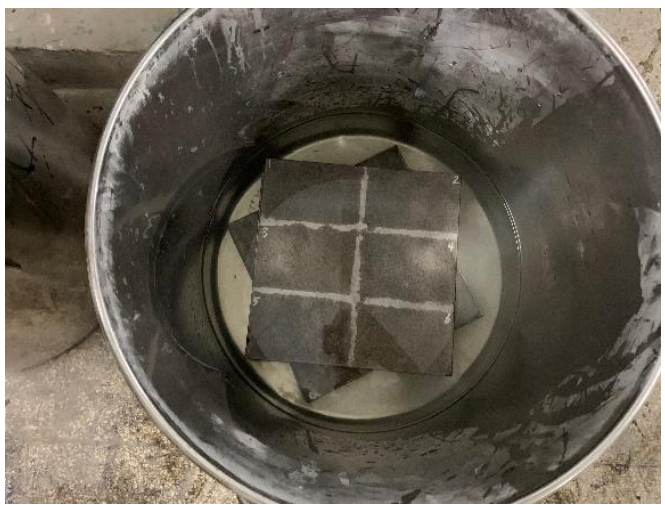

(a)

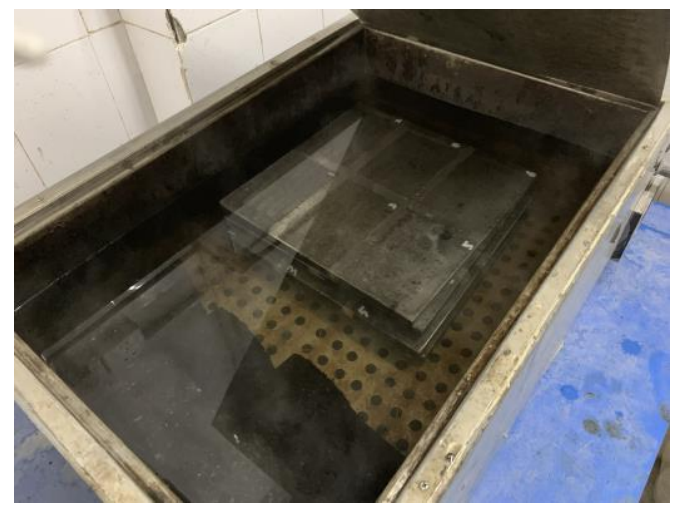

(b)

Figure 4. Epoxy maintenance: (a) Room temperature saturated salt solution water bath; (b) $60{ }^{\circ} \mathrm{C}$ water bath. 
(5) The pull-out test was carried out after maintenance, using high-strength epoxy $\mathrm{AB}$ adhesive as the binder for the pull-out head, see Figure 5 for the pull-out test.

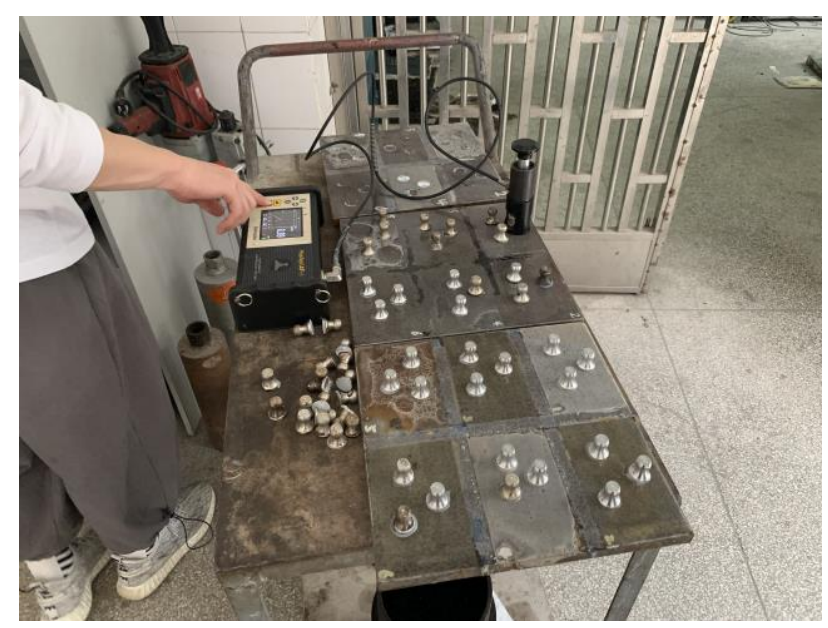

Figure 5. Pull-out tests.

\section{Results and Discussion}

\subsection{The Effect of Coating with Different Epoxy Resin Waterproofing Tack Coat Oils}

From the viewpoint of the coating effect on the surface of the steel plate, combination 3 and combination 6 have the best mixing effect and can adhere to the steel plate evenly and effectively; combination 1 has more small bubbles on the surface, combination 2 and combination 4 have more bumps, as shown in Figure 6, combination 5 has more surface tension after mixing, and the epoxy resin shrinks and the steel plate is exposed, so the construction effect is the worst.

For the steel plate room temperature water bath, room temperature salt bath and $60{ }^{\circ} \mathrm{C}$ water bath immersion test, the test results are shown in Figure 7. As can be seen from Figure 7 , after one week in the room temperature water bath and the $60{ }^{\circ} \mathrm{C}$ water bath, areas 1,4 , and 5 showed obvious rust stains and the epoxy resin had a poor isolation effect; after one week in the room temperature salt bath, area 5 showed obvious rust stains and the other areas showed no obvious changes.

In terms of epoxy coating effect, combination 3 (component $\mathrm{A}_{1}$ (high viscosity) and component $\mathrm{B}_{3}$ (high viscosity)) and combination 6 (component $\mathrm{A}_{2}$ (low viscosity) and component $\mathrm{B}_{3}$ (high viscosity)) are significantly better than the other component combinations, i.e., component $\mathrm{B}$ must be high viscosity when selecting components.

\subsection{Influence of Different Epoxy Resin Waterproofing Tack Coat Oils on Pull-Out Strength in Different Environments}

The results of the room temperature water bath are shown in Figure 8. In the room temperature water bath environment, with the increase of water bath time, the drawing strength of all other combinations increased first and then decreased except for combination 5. However, the pulling strength of combination 2 and combination 6 in the eighth week was still higher than the pulling strength in the first week, and the pulling strength of the other combinations in the eighth week was slightly lower than the pulling strength in the first week. 


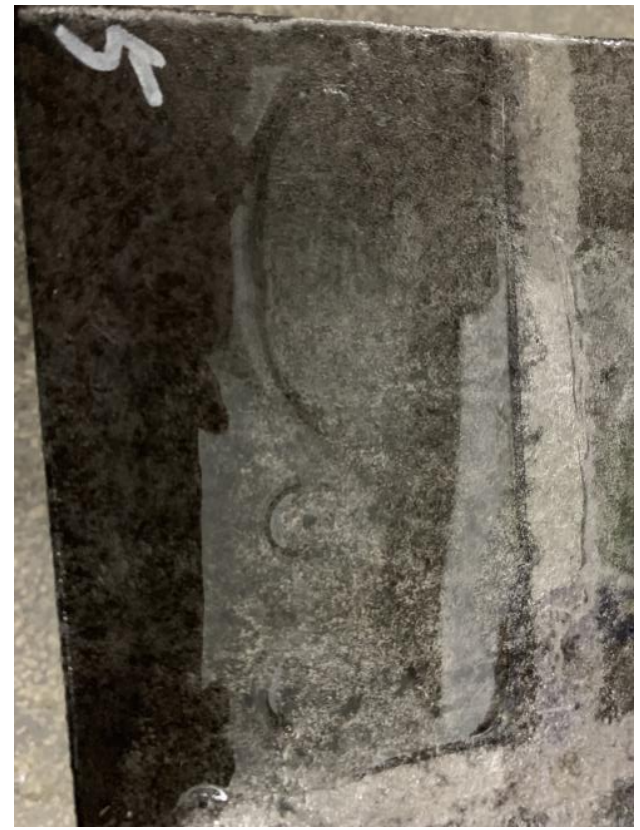

Figure 6. Combination 5 shows shrinkage of the adhesive layer oil after coating, with the steel plate exposed.

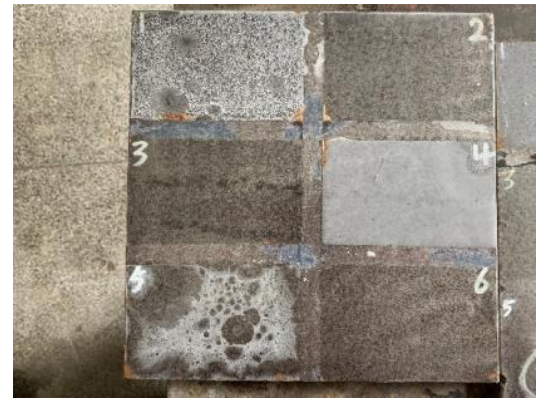

(a)

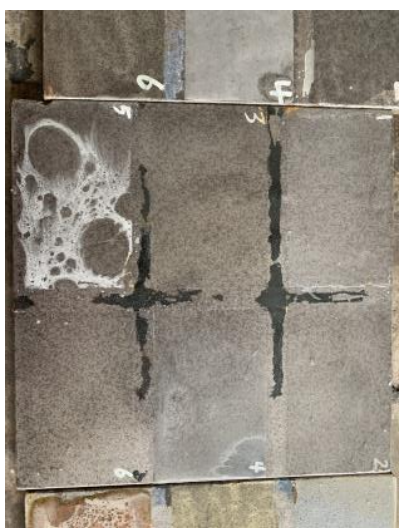

(b)

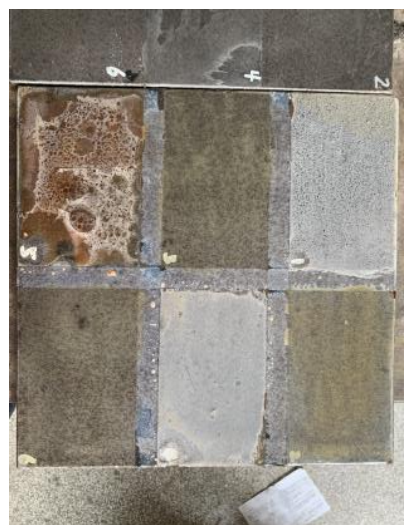

(c)

Figure 7. Maintenance of the specimen for the first week: (a) Room-temperature water bath diagram for the first week; (b) Room-temperature salt bath condition for the first week; (c) Room-temperature $60{ }^{\circ} \mathrm{C}$ water bath for the first week.

As a whole, except for combination 1 , the effect of the room temperature water bath for 8 weeks on the drawing strength was not significant.

The results of the room temperature salt bath are shown in Figure 9. The initial values of the pull-out strength of combinations 3 to 6 were slightly higher than those of combinations 1 and 2 in the room temperature salt bath environment. The pull-out strength of combination 1 at week 8 was still higher than that at week 1 , while the pull-out strength of combination 2 and combination 5 showed a significant decrease after week 2 . The pulling strength of Combination 3 and Combination 6 tends to decrease gradually and decreases significantly after the fourth week. The pulling strength of combination 4 showed a significant decay after the first week. 


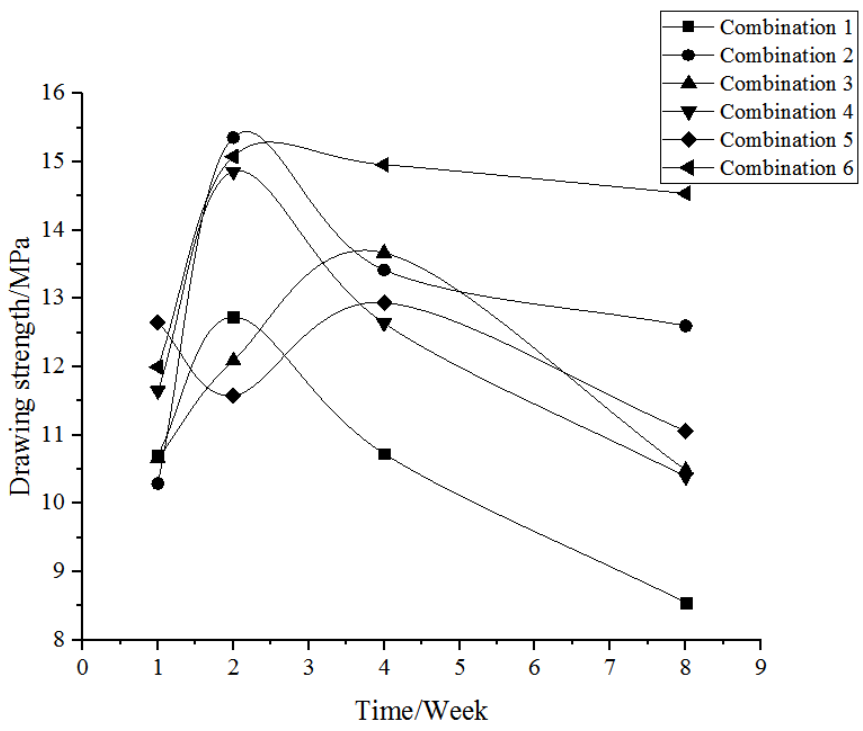

Figure 8. Room temperature water bath drawing strength diagram.

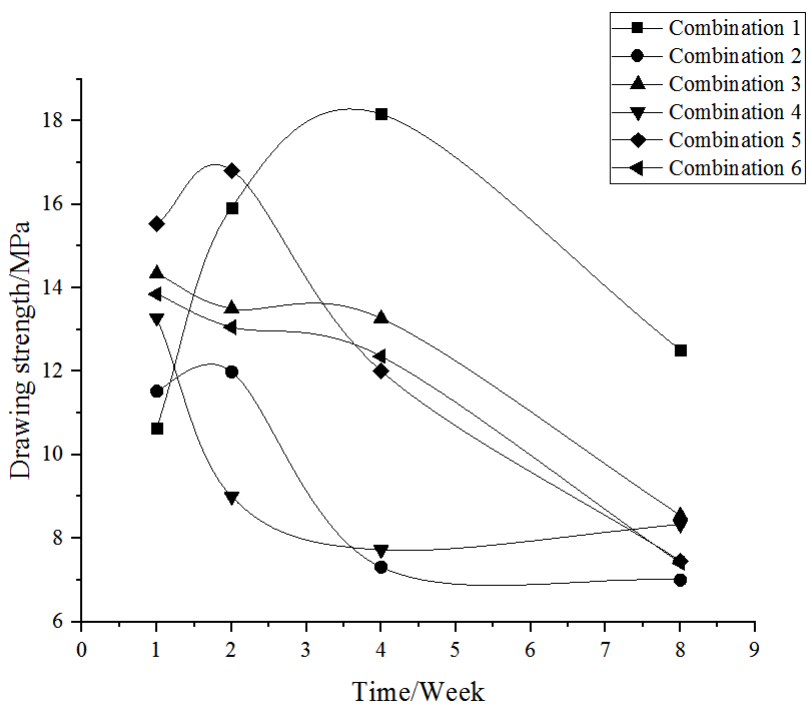

Figure 9. Room temperature salt bath pulling strength.

Taking an overall view, combinations 1, 3, and 6 showed no significant attenuation in pulling strength after 4 weeks in a room temperature salt bath.

The results of the $60^{\circ} \mathrm{C}$ water bath are shown in Figure 10. In the $60^{\circ} \mathrm{C}$ water bath environment, the initial values of the pull-out strength of combination 3 and combination 5 are slightly higher than those of the other combinations. As the salt bath time increased, the pull-out strength of combination 5 showed a gradual decrease, and the other combinations showed a trend of increasing and then decreasing. Combination 2, combination 3 , combination 5, and combination 6 still had a high pull-out strength in the second week, but all showed an increased decay after 2 weeks.

On the whole, combinations 3 and 5 showed no significant changes in pulling strength after 2 weeks in the $60^{\circ} \mathrm{C}$ water bath, and the pulling strength values were relatively stable.

In summary, except for combination 1, the effect of a room temperature water bath for 8 weeks on the drawing strength was not significant. Combination 1, combination 3 , and combination 6 did not show any significant attenuation in drawing strength after 4 weeks in a room temperature salt bath. Combination 3 and combination 5 showed no significant change in pulling strength after 2 weeks in a $60{ }^{\circ} \mathrm{C}$ water bath and the pulling strength values were relatively stable. The epoxy resin bonding oil of combination 5 is less effective 
due to the exposed steel plate after application. Considering the most unfavorable factors, combination 3 is the best combination of waterproofing bonding layer material that can maintain a large pull-out strength value in a water bath at $60^{\circ} \mathrm{C}$ for 2 weeks.

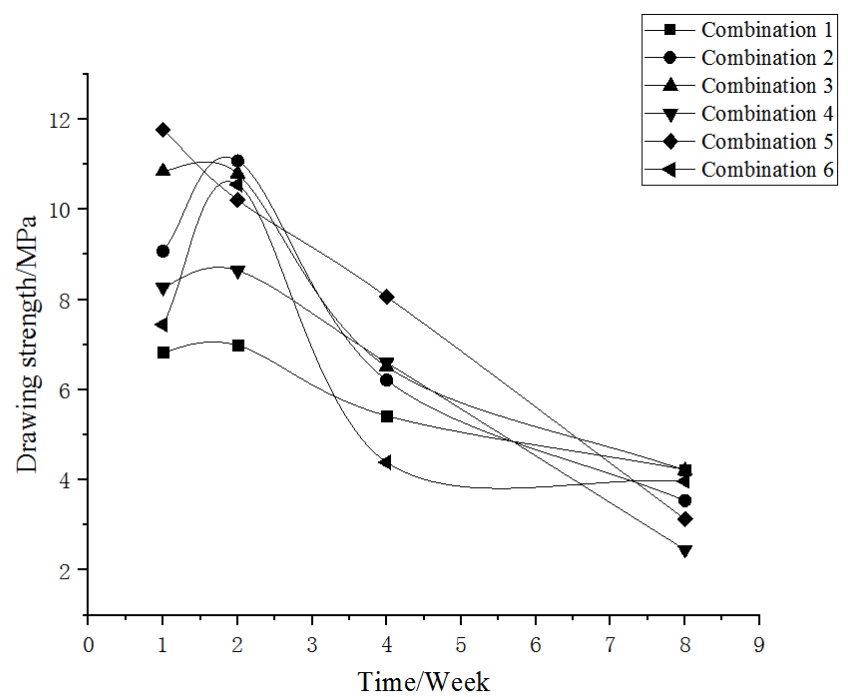

Figure 10. $60^{\circ} \mathrm{C}$ water bath pulling strength.

\section{Design of Mixture Proportion of Pavement Lower Layer}

In this study, an open-graded epoxy bituminous concrete was used for the lower layer of the pavement to drain the water entering the interior of the structural layer in time through large pores. The mixture is designed without changing the permanent load of the bridge, that is, without changing the thickness of the structural layer.

\subsection{Mixing Ratio Design}

In this paper, the design of drained epoxy asphalt mixes is based on the OGFC-13 mix grading curve. Three types of aggregates, $10 \sim 15 \mathrm{~cm}, 5 \sim 10 \mathrm{~cm}$, and $0 \sim 3 \mathrm{~cm}$, with mineral powder, lignin fiber, epoxy resin, and matrix asphalt, were used for the mix ratio design, and the test results of various raw materials met the specification requirements [29-31].

Within the design range of the OGFC-13 gradation, three sets of preliminary gradations with different coarsenesses were designed by adjusting the proportion of each ore material. The blending ratios and sieve passage rates for each grade of the preliminary grades are shown in Tables 6 and 7, respectively.

Table 6. Mixing ratios for each grade of the preliminary grading (unit: \%).

\begin{tabular}{cccccccc}
\hline Preliminary Gradation Type & $\mathbf{1 0 ~ 1 5} \mathbf{~ m m}$ & $\mathbf{5 ~ 1 0 ~} \mathbf{~ m}$ & $\mathbf{0 ~ 3 ~} \mathbf{~ m}$ & Fine Ore & Cement & Fiber \\
\hline OGFC-13-11.5 & 36 & 52 & 9 & 1.5 & 1.5 & 0.3 \\
\hline OGFC-13-14.2 & 33 & 52 & 12 & 1.5 & 1.5 & 0.3 \\
\hline OGFC-13-17.0 & 30 & 52 & 15 & 1.5 & 1.5 & 0.3 \\
\hline
\end{tabular}

Note: Fibers are wood fibers and the proportion is a percentage of the total mass of the asphalt mix.

Table 7. Passage rates for each sieve hole of the initial test ore grade.

\begin{tabular}{|c|c|c|c|c|c|c|c|c|c|c|}
\hline \multirow{2}{*}{ Preliminary Gradation Type } & \multicolumn{10}{|c|}{ Mass Percentage (\%) through the Following Mesh (Square Mesh mm) } \\
\hline & 16 & 13.2 & 9.5 & 4.75 & 2.36 & 1.18 & 0.6 & 0.3 & 0.15 & 0.075 \\
\hline OGFC-13-11.5 & 100.0 & 98.1 & 62.4 & 13.7 & 11.5 & 8.8 & 7.0 & 5.5 & 4.4 & 3.6 \\
\hline OGFC-13-14.2 & 100.0 & 98.3 & 65.3 & 16.7 & 14.2 & 10.6 & 8.2 & 6.2 & 4.8 & 3.8 \\
\hline OGFC-13-17.0 & 100.0 & 98.4 & 68.2 & 19.7 & 17.0 & 12.5 & 9.5 & 6.9 & 5.2 & 4.0 \\
\hline
\end{tabular}


Table 8 gives the initial test bitumen dosage of aggregates for each group of minerals $\mathrm{P}_{\mathrm{b}}$.

Table 8. Gradation test parameters.

\begin{tabular}{ccc}
\hline Preliminary Gradation Type & Initial Asphalt Content $\mathbf{P}_{\mathbf{b}}$ & \multicolumn{2}{c}{ Initial Asphalt-Aggregate Ratio } \\
\hline OGFC-13-11.5 & 4.57 & 4.8 \\
\hline OGFC-13-14.2 & 4.98 & 5.2 \\
\hline OGFC-13-17.0 & 5.39 & 5.7 \\
\hline
\end{tabular}

According to Table 9, the results of the Marshall test of the initial grading of OGFC-13 asphalt mix, and also based on the expected void ratio of $21.0 \%$, the passage rate of $2.36 \mathrm{~mm}$ was determined to be $14.2 \%$, and the asphalt-aggregate ratio of the OGFC-13 asphalt mix was initially determined to be $5.2 \%$, the ratio of asphalt to epoxy in the asphalt-aggregate ratio was $1: 1$, and the fiber admixture was $0.3 \%$ of the mix.

Table 9. OGFC-13 asphalt mixture preliminary gradation Marshall test results.

\begin{tabular}{cccc}
\hline Test Item & \multicolumn{3}{c}{$\mathbf{2 . 3 6} \mathbf{~ m m ~ S i e v e ~ P a s s ~ R a t e ~}$} \\
\cline { 2 - 4 } & $\mathbf{1 1 . 5 \%}$ & $\mathbf{1 4 . 2} \%$ & $\mathbf{1 7 . 0}$ \\
\hline Asphalt-aggregate ratio (\%) & 4.8 & 5.2 & 5.7 \\
\hline Maximum relative theoretical density & 2.672 & 2.656 & 2.637 \\
\hline Gross volume relative density of the specimen & 2.041 & 2.100 & 2.156 \\
\hline Void fraction VV (\%) & 23.6 & 20.9 & 29.2 \\
\hline Ore material clearance rate VMA (\%) & 32.7 & 31.0 & 29.3 \\
\hline Saturation VFA (\%) & 27.8 & 32.4 & 37.8 \\
\hline
\end{tabular}

The Marshall specimens and rutting plates were prepared with an asphalt-aggregate ratio of $5.2 \%$, and the specimens were tested for high-temperature stability, low-temperature crack resistance, and water stability according to standard conditioning [32-34]. The test results are shown in Table 10.

Table 10. Results of OGFC-13 optimum asphalt-aggregate ratio tests.

\begin{tabular}{|c|c|c|c|c|c|}
\hline Test & Index & Standard & Unit & Measured Value & Required Value \\
\hline Immersion Marshall test & Residual stability & $\begin{array}{c}\text { JTG E20 } \\
\text { T0709-2011 }\end{array}$ & $\%$ & 92.8 & $\geq 90$ \\
\hline Freeze-thaw splitting test & Residual strength ratio & $\begin{array}{c}\text { JTG E20 } \\
\text { T0729-2011 }\end{array}$ & $\%$ & 89.5 & $\geq 85$ \\
\hline Rutting test at $60^{\circ} \mathrm{C}$ & Dynamic stability DS value & $\begin{array}{c}\text { JTG E20 } \\
\text { T0719-2011 }\end{array}$ & Times/mm & 17,800 & $\geq 7000$ \\
\hline Low-temperature bending test & Maximum flexural strain & $\begin{array}{c}\text { JTG E20 } \\
\text { T0715-2011 }\end{array}$ & $\mu \varepsilon$ & 3412 & $\geq 2500$ \\
\hline Permeability test & Water seepage coefficient & $\begin{array}{c}\text { JTG E20 } \\
\text { T0730-2011 }\end{array}$ & $\mathrm{mL} / \mathrm{min}$ & 5225 & 4800 \\
\hline Analysis leakage test & Run-off loss & $\begin{array}{c}\text { JTG E20 } \\
\text { T0732-2011 }\end{array}$ & $\%$ & 0.23 & $\leq 0.3$ \\
\hline Fort Kenta flight test & Dispersion loss rate & $\begin{array}{c}\text { JTG E20 } \\
\text { T0733-2011 }\end{array}$ & $\%$ & 7.5 & $\leq 10$ \\
\hline
\end{tabular}

\subsection{Effect of Void Ratio on the Performance of Drained Mixes}

According to Table 9, a plot of $2.36 \mathrm{~mm}$ sieve passage rate versus void fraction can be fitted (e.g., Figure 11). According to the fitted \%, equation, the passage rate of $2.36 \mathrm{~mm}$ 
sieve in the grading curve of the drained epoxy asphalt mix was adjusted to synthesize grading curves with void ratios of $18 \%, 20 \%, 22 \%$, and $24 \%$ respectively. Formed rutting slabs were subjected to water penetration tests and dynamic stability tests at $60^{\circ} \mathrm{C}$. The test results are shown in Figure 12. As can be seen from Figure 12, when the void ratio is at $18 \%$, the water penetration coefficient can meet the required value, but is closer to the required value; when the void ratio is greater than $22 \%$, the high-temperature stability of the mix is relatively poor, and under extreme loading conditions, the paving layer may show rutting disease. Comprehensive water infiltration coefficient and dynamic stability index, it is recommended that the void ratio of drainage epoxy asphalt mixture is controlled at $20 \sim 22 \%$.

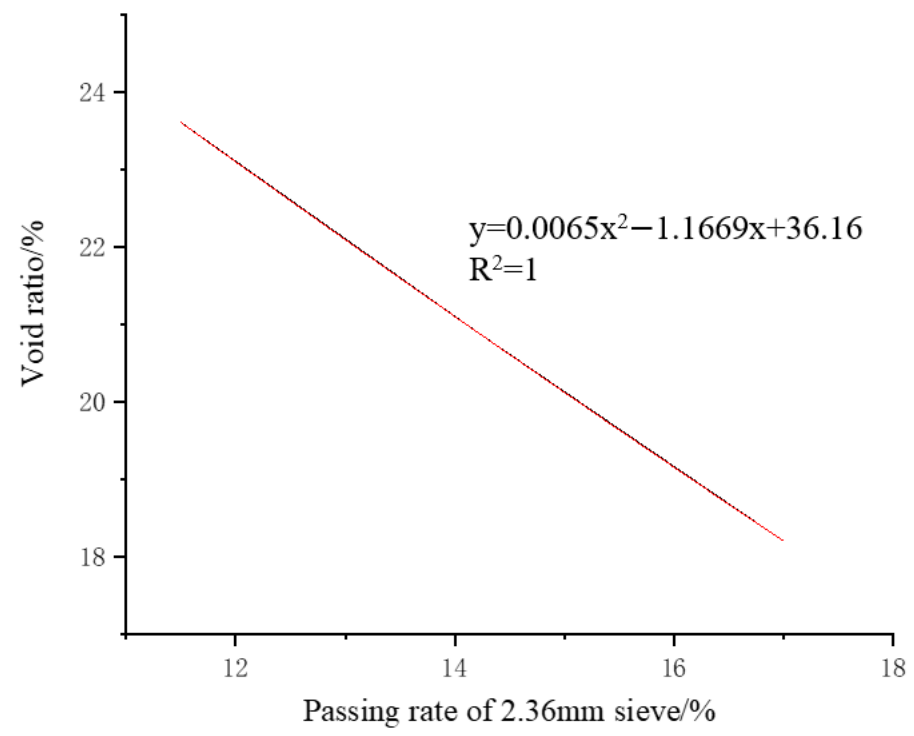

Figure 11. Relationship between passage rate and void fraction for $2.36 \mathrm{~mm}$ sieve pores.

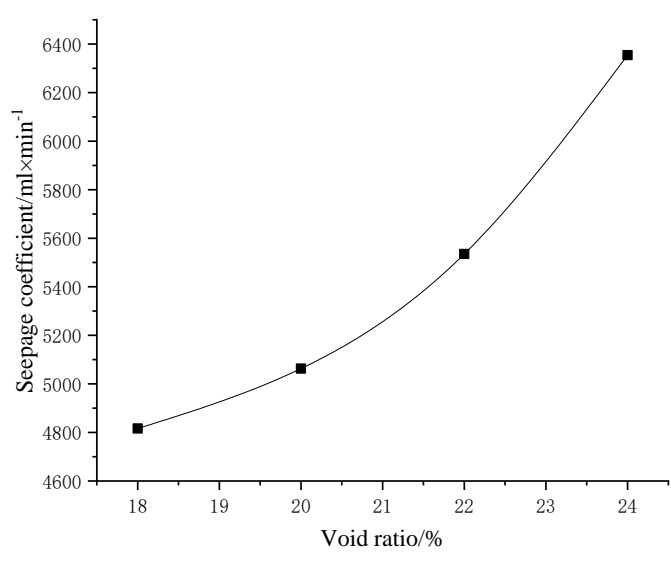

(a)

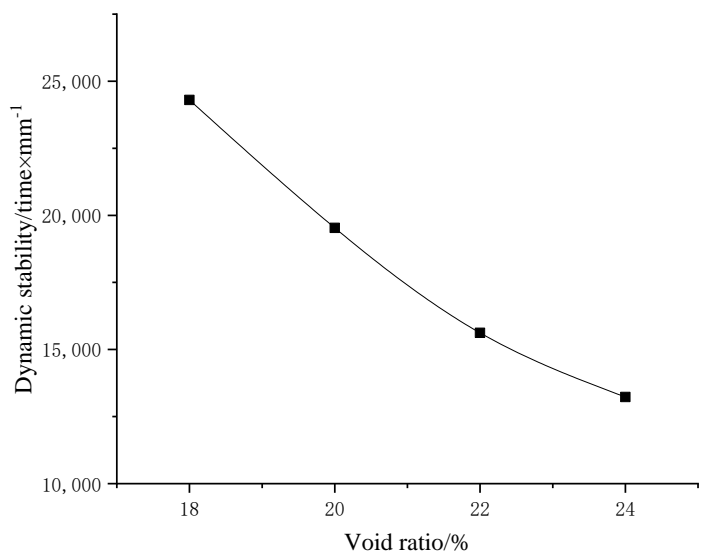

(b)

Figure 12. Relationship between void ratio and performance of drained epoxy asphalt mixture: (a) Diagram of void ratio versus permeability coefficient; (b) Diagram of void ratio and dynamic stability.

\section{Checking Calculation of Drainage Capacity under Pavement}

In the previous part, the feasibility of the pavement performance of the lower layer of drainage pavement is verified through the mix design. In this paper, the seepage analysis module seepage/w in GeoStudio software is used for the seepage analysis of the pavement. By setting the asphalt pavement models with different void ratios, the time of water 
discharge in the structural layer is checked to obtain the void ratio of the mixture that meets the requirements.

\subsection{Seepage State Analysis}

The upper layer of the paving is a dense-graded asphalt pavement with small voids, so there is no large amount of water infiltrating into the lower layer of the paving through the upper layer of the paving, and the lower layer of the paving is proposed to be an open-graded drainage type pavement with a larger void rate than that of the upper layer of the paving. When a small amount of water infiltrates into the lower pavement from the local area, the infiltrated water can move according to the cross slope of the bridge deck, and the infiltrated water can never fill up the lower pavement, so the lower pavement is always in a non-saturated state. The pavement subgrade is in an unsaturated state, i.e., the interior of the pavement substructure is a state where gas, liquid, and solid forms co-exist. In this state, the seepage of asphalt pavement is affected by load, temperature, seepage volume, and unsaturated suction, and the seepage forces are very complex [11]. This paper uses seepage analysis software to simulate the actual situation, as it is difficult to calculate the seepage situation in this state comprehensively and accurately.

\subsection{Criteria for Assessing the Drainage Capacity of Paving Layers}

Referring to the AASHTO GDHS-4-1993, the drainage quality is classified into five grades of excellent, good, moderate, poor, and very poor when draining $50 \%$ of the internal water used in the pavement layer for pavement drainage design [35]. The drainage capacity assessment criteria are shown in Table 11. Steel bridge decks are heavily loaded with traffic and are generally in rainy areas with frequent rainfall. If the drainage capacity of the pavement does not reach excellent, the pavement is prone to water damage under the action of dynamic water pressure under the action of traffic load, so this study requires that the drainage capacity of the pavement should reach excellent.

Table 11. Performance rating of paving layer drainage capacity.

\begin{tabular}{cc}
\hline Drainage Performance & Drainage Time (Discharge 50\%) \\
\hline Excellent & $2 \mathrm{~h}$ \\
\hline Good & 2 days \\
\hline Medium & 1 week \\
\hline Poor & 1 month \\
\hline Very poor & Undrained \\
\hline
\end{tabular}

\subsection{Paving Layer Parameters}

The general thickness of the steel bridge deck pavement layer is $6 \sim 7 \mathrm{~cm}$, of which the underlayment layer is generally $3 \sim 3.5 \mathrm{~cm}$. In this paper, $3.5 \mathrm{~cm}$ thick hot mix epoxy asphalt concrete was used as an example to calculate the thickness of drainage pavement structure layer under different void ratios without changing the self-weight of the underlayment layer. The design void ratio of hot mix epoxy asphalt concrete is generally $1.5 \%$, and the gross volume relative density is about 2.60, with a unit weight of about $91 \mathrm{~kg}$ per square meter, while the drainage pavement void ratio is generally $18-24 \%$, corresponding to a gross volume relative density of about 2.02-2.20, resulting in a calculated thickness of $4.1-4.5 \mathrm{~cm}$.

To be conservative, the thickness of the lower layer of the pavement was set at $4.0 \mathrm{~cm}$ and the void ratio was set at $18 \%, 20 \%$, and $22 \%$ to calculate the time required to drain the water inside the pavement. When the parameters are set, the void rate should be finite, so it is also necessary to measure the void rate and the effective void rate, fit the relationship between the two, determine the effective void rate corresponding to $18 \%, 20 \%$, and $22 \%$ 
of the void rate, the relationship between the void rate and the effective void rate graph as Figure 13.

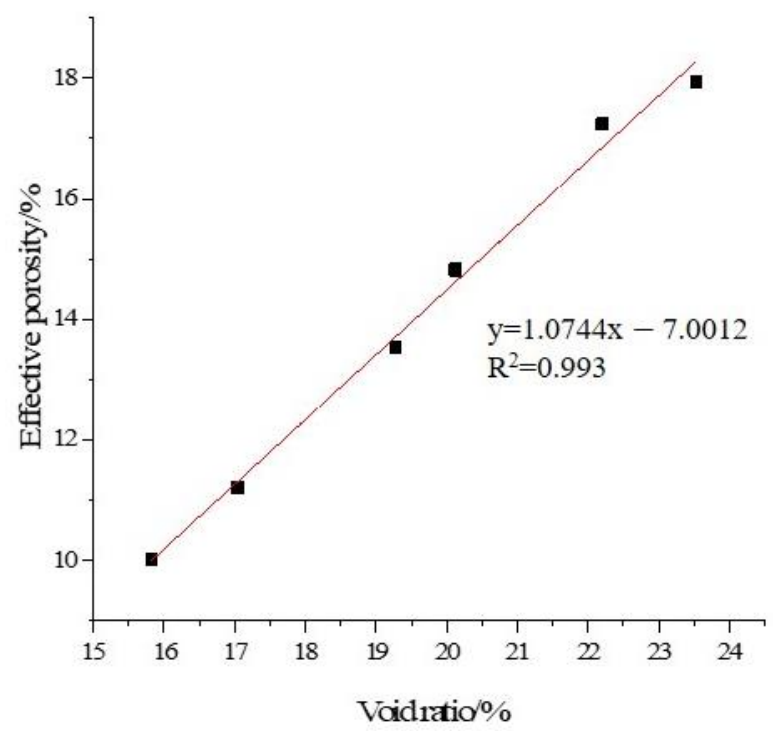

Figure 13. Void ratio versus effective void ratio.

\subsection{Seepage Calculation Model}

Due to the dense-graded asphalt pavement on top of the pavement, the pore water in the lower layer of the pavement never reaches a saturated state. The analysis is therefore carried out under the most unfavorable conditions, assuming that the initial condition of seepage in the lower pavement layer is saturated and that the drainage process is transient. The pavement drainage process was modeled and analyzed using a $22 \%$ void ratio as an example.

\section{(1) Modeling}

The width of the road surface is $15.5 \mathrm{~m}$, the thickness of the pavement layer is $4.0 \mathrm{~cm}$, the cross slope of the road surface is set at $2 \%$, and rectangular drainage ditches are set on the side of the road. The model is meshed with a quadrilateral grid, with a cell size of $0.01 \mathrm{~m}$, a total of 7755 nodes, and 6200 cells, and the local diagram of the model is shown in Figure 14.

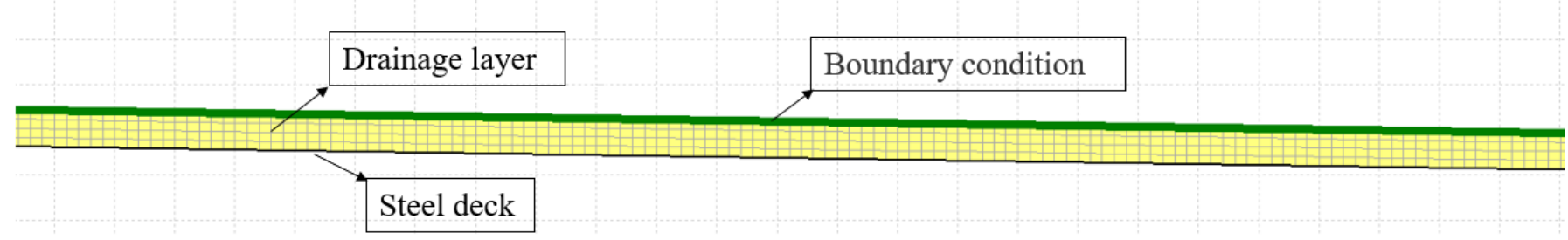

Figure 14. Partial schematic of the model.

\section{(2) Material set-up}

In unsaturated asphalt pavements due to the presence of gas, a small amount of air in the form of bubbles makes the water in the voids compressible, i.e., a larger amount of air forms a continuous gas phase in the asphalt concrete. At this stage, a significant difference between the pore air pressure and the pore water pressure begins to appear, thus the matrix suction is constantly changing as the volumetric water content varies. The material setting mainly requires the determination of the volumetric water content function and the hydraulic conductivity function. The volumetric water content function was selected as the volumetric water content data point function, estimated as the grain 
size data, with the saturated soil water content set at $16.64 \%$, maximum suction at $20 \mathrm{kPa}$, compressibility set at $1.0 \times 10^{-0.5} \mathrm{kPa}$, and the volumetric water content function as shown in Figure 15a; the hydraulic conductivity function was estimated as Van Genuchten, with a permeability coefficient of $0.0206 \mathrm{~m} / \mathrm{s}$ and residual water content is $10 \%$ of the saturated soil water content, and the hydraulic conductivity function is shown in Figure $15 \mathrm{~b}$.

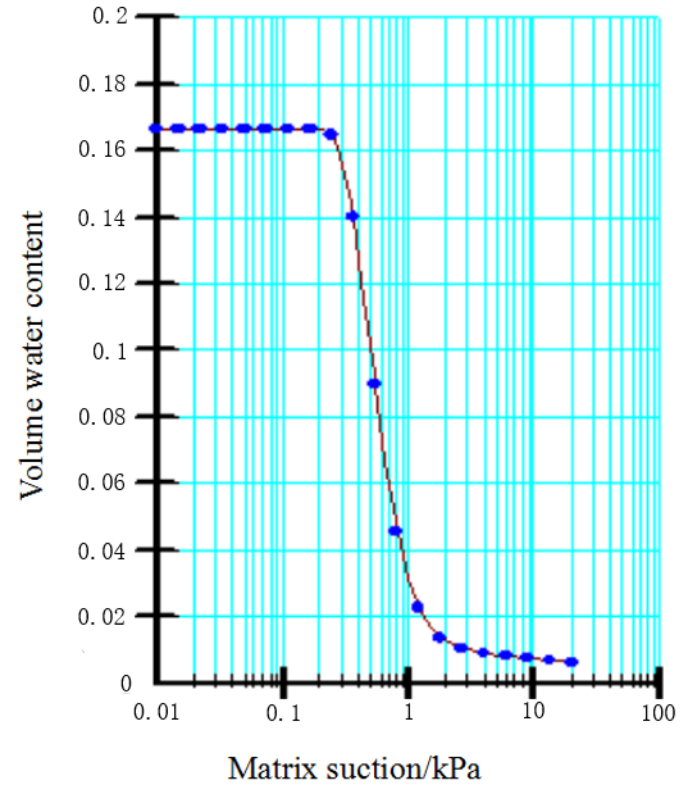

(a)

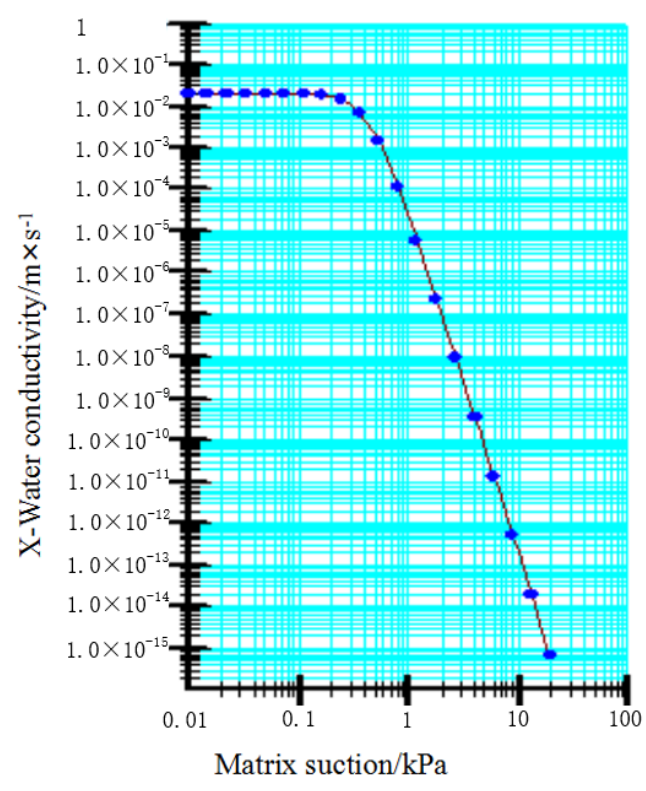

(b)

Figure 15. Material parameter settings: (a) Volumetric water content function; (b) Hydraulic conductivity function.

\section{(3) Boundary condition setting}

The model simulates the internal drainage of the paving layer, the initial conditions need to be determined during the analysis, the paving layer underneath is a permeable material, the lower-lying groove is a steel plate, the steel plate is impermeable, the initial conditions are set to the initial head coincides with the steel plate. A unit flow function was set up on the surface of the paving layer to simulate the paving layer filling process. After the paving layer was full of water, the surface of the paving layer was a free boundary, and then the drainage analysis started, with the drainage outlet being the roadside drainage ditch and zero pressure head. The location $12.5 \mathrm{~m}$ from the middle (junction of the slow lane and hard shoulder) was selected as the model analysis point to analyze the variation of the internal volume water content of the paving layer at this location with time. When the internal volume water content of the paving layer at this location is close to the set residual water content, it can be judged that the water inside the paving layer has been discharged.

\section{(4) Transient analysis}

We set the model analysis time with a duration of 15 days and a step size of $2 \mathrm{~h}$. Follow the steps above to analyze models with $18 \%$ and $20 \%$ pavement void fractions.

\subsection{Results Analysis}

Based on the results of the analysis, the variation of the volumetric water content inside the paving layer at a distance of $12.5 \mathrm{~m}$ from the center with time is given in Figure 16. It shows that the paving with $18 \%, 20 \%$, and $22 \%$ void ratios are all able to drain $50 \%$ of the water inside the paving within $2 \mathrm{~h}$, with excellent drainage capacity. 


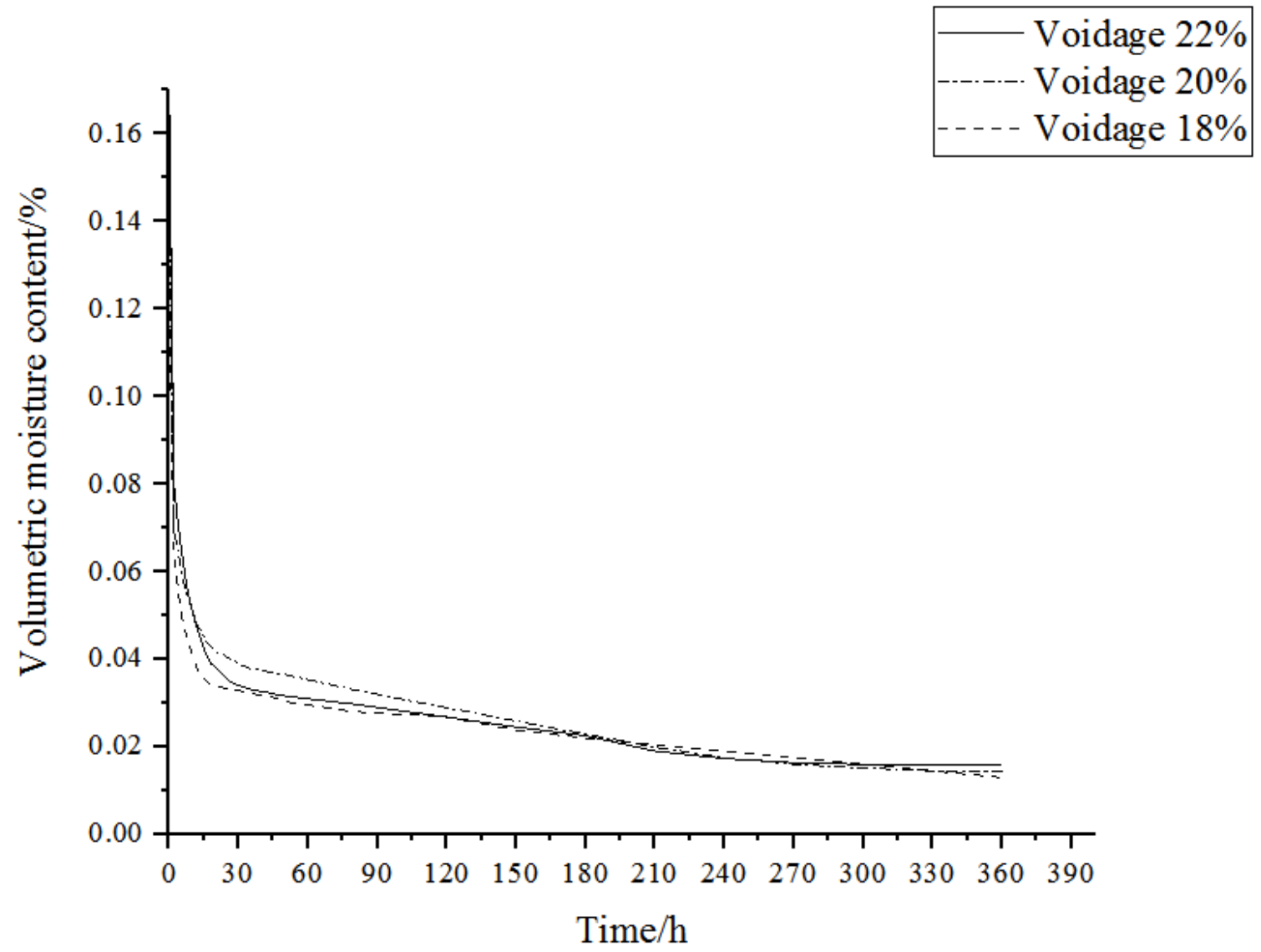

Figure 16. Internal volumetric water content of the paving layer as a function of time.

When drained to $270 \mathrm{~h}$, the pavement with a void ratio of $22 \%$ reaches the designed residual water content, there is relatively little water inside the pavement and basically, no water is discharged afterward. When drained to $330 \mathrm{~h}$, the pavement with a void ratio of $20 \%$ reaches the designed residual water content, there is relatively little water inside the pavement and basically, no water is discharged afterward. When the paving layer with a void ratio of $18 \%$ was drained to $360 \mathrm{~h}$, the water inside the paving layer was greater than the design residual water content and the drainage was still not complete. From the water immersion on the epoxy resin bonding layer of the test results can be seen, waterproofing bonding layer material can be in the $60{ }^{\circ} \mathrm{C}$ water bath for 2 weeks ( $336 \mathrm{~h}$ ) to maintain a large pull-out strength value. Combined with the test results of the influence of water immersion on the epoxy resin adhesive layer and the test results of the mixture ratio of the lower layer of the pavement, the target void ratio of the pavement layer is suggested to be $20 \sim 22 \%$.

\section{Conclusions}

Through different components of epoxy resin materials, the steel bridge deck waterproofing binder layer was developed and the effect of different environments on the performance of the waterproofing binder layer was studied through different permaculture conditions. Based on the developed waterproofing binder layer, a new steel bridge deck paving system was developed. The appropriate porosity of the pavement layer is studied through laboratory tests and seepage analysis, with the following main findings:

- Considering the most unfavorable factors, combination 3 is the best combination of waterproofing bonding layer material that can maintain a large pull-out strength value in a water bath at $60{ }^{\circ} \mathrm{C}$ for 2 weeks.

- $\quad$ Through the mix proportion design of drainage epoxy asphalt mixture, combined with the permeability coefficient and dynamic stability index, it is suggested that the porosity of drainage epoxy asphalt mixture should be controlled in $20 \sim 22 \%$. 
- According to the analysis results of the seepage analysis software, the paving with 18,20 , and $22 \%$ void ratio could drain $50 \%$ of the water inside the paving within $2 \mathrm{~h}$, and the drainage capacity was excellent. However, in terms of the drainage cycle, the paving with an $18 \%$ void ratio failed to drain the internal water in time. Comprehensive modeling analysis and indoor test results suggest that the void ratio of drained epoxy asphalt mixes should be controlled at 20 to $22 \%$.

- In this paper, the lower layer of drainage pavement is studied from the mixture ratio design and finite element simulation, and the feasibility of the pavement scheme is preliminarily verified. The construction research of the experimental bridge test section can be carried out to verify the use of the pavement scheme.

Author Contributions: Conceptualization, W.N. and D.W.; methodology, W.N. and D.W.; software, J.H. and J.Y.; validation, W.N. and D.W.; formal analysis, W.N., J.H. and C.J.; investigation, J.Y.; data curation, W.N.; writing—original draft preparation, W.N.; writing-review and editing, W.N., J.H. and C.J.; supervision, D.W.; project administration, D.W. and C.J.; funding acquisition, D.W. All authors have read and agreed to the published version of the manuscript.

Funding: This research was funded by the Natural Science Fund of Guangdong Province, grant number 2019A1515011965, and Natural Science Foundation of China, grant number 51808228.

Institutional Review Board Statement: Not applicable.

Informed Consent Statement: Not applicable.

Data Availability Statement: The data presented in this study are available on request from the corresponding author.

Conflicts of Interest: The authors declare no conflict of interest.

\section{References}

1. Su, N.; Lou, L.; Amirkhanian, A.; Amirkhanian, S.N.; Xiao, F. Assessment of effective patching material for concrete bridge deck-A review. Constr. Build. Mater. 2021, 293, 123520. [CrossRef]

2. Kim, H.; Moon, B.; Hu, X.; Lee, H.; Ryu, G.-S.; Koh, K.-T.; Joh, C.; Kim, B.-S.; Keierleber, B. Construction and Performance Monitoring of Innovative Ultra-High-Performance Concrete Bridge. Infrastructures 2021, 6, 121. [CrossRef]

3. Wang, S.; Zhang, C.; Pan, Z.; Sun, D.; Zhou, A.; Xie, S.; Wang, J.; Zou, J. Microplastics in wild freshwater fish of different feeding habits from Beijiang and Pearl River Delta regions, south China. Chemosphere 2020, 258, 127345. [CrossRef]

4. Chen, Z.-Y.; Li, C.-X.; He, J.; Xin, H.-H. Retrofit Fatigue Cracked Diaphragm Cutouts Using Improved Geometry in Orthotropic Steel Decks. Appl. Sci. 2020, 10, 3983. [CrossRef]

5. Nie, W.; Wang, D.; Sun, Y.; Xu, W.; Xiao, X. Integrated Design of Structure and Material of Epoxy Asphalt Mixture Used in Steel Bridge Deck Pavement. Buildings 2021, 12, 9. [CrossRef]

6. Xu, X.; Gu, Y.; Huang, W.; Chen, D.; Zhang, C.; Yang, X. Structural Optimization of Steel—Epoxy Asphalt Pavement Based on Orthogonal Design and GA-BP Algorithm. Crystals 2021, 11, 417. [CrossRef]

7. Chen, J.; Dan, H.; Ding, Y.; Gao, Y.; Guo, M.; Guo, S.; Han, B.; Hong, B.; Hou, Y.; Hu, C.; et al. New innovations in pavement materials and engineering: A review on pavement engineering research. J. Traffic Transp. Eng. 2021, 8, 815-999. [CrossRef]

8. Yan, C.X.; Li, Z.G.; Su, B. Optimization Study on Paving Structure of Steel Bridge Deck Suitable for the Chinese 2th Climate Zone. In Applied Mechanics and Materials; Trans Tech Publications Ltd.: Bäch, Switzerland, 2013.

9. Huang, W.; Pei, M.; Liu, X.; Wei, Y. Design and construction of super-long span bridges in China: Review and future perspectives. Front. Struct. Civ. Eng. 2020, 14, 803-838. [CrossRef]

10. Edwards, Y.; Westergren, P. Polymer Modified Waterproofing and Pavement System for the High Coast Bridge in Sweden: Research, Testing and Experience; VTI Rapport 430A; Statens Väg-Och Transportforskningsinstitut: Linköping, Sweden, 2001.

11. Bas, S.; Apaydin, N.M.; Ilki, A.; Catbas, F.N. Structural health monitoring system of the long-span bridges in Turkey. Struct. Infrastruct. Eng. 2018, 14, 425-444. [CrossRef]

12. Guo, T.; Liu, T.; Li, A.Q. Pavement rehabilitation strategy selection for steel suspension bridges based on probabilistic life-cycle cost analysis. J. Perform. Constr. Facil. 2012, 26, 76-83. [CrossRef]

13. Kitagawa, M. Technology of the akashi kaikyo bridge. Struct. Control Health Monit. 2004, 11, 75-90. [CrossRef]

14. Shao, X.; Deng, L.; Cao, J. Innovative steel-UHPC composite bridge girders for long-span bridges. Front. Struct. Civ. Eng. 2019, 13, 981-989. [CrossRef]

15. Huang, Q.; Qian, Z.; Chen, L.; Zhang, M.; Zhang, X.; Sun, J.; Hu, J. Evaluation of epoxy asphalt rubber with silane coupling agent used as tack coat for seasonally frozen orthotropic steel bridge decks. Constr. Build. Mater. 2020, 241, 117957. [CrossRef] 
16. Guo, S.; Si, R.; Dai, Q.; You, Z.; Ma, Y.; Wang, J. A critical review of corrosion development and rust removal techniques on the structural/environmental performance of corroded steel bridges. J. Clean. Prod. 2019, 233, 126-146. [CrossRef]

17. Xin, H.; Mosallam, A.; Correia, J.A.; Liu, Y.; He, J.; Sun, Y. Material-structure integrated design optimization of GFRP bridge deck on steel girder. Structures 2020, 27, 1222-1230. [CrossRef]

18. Chelelgo, K.; Gariy, Z.C.A.; Shitote, S.M. Laboratory Mix Design of Cold Bitumen Emulsion Mixtures Incorporating Reclaimed Asphalt and Virgin Aggregates. Buildings 2018, 8, 177. [CrossRef]

19. Yan, H.; Cai, M.; Song, S.; Huang, Y.; Fan, X.; Ye, X.; Li, H.; Li, W.; Zhu, M. Self-dispersing complex lithium-based thickener fiber for high-performance anti-corrosion/wear epoxy coating filler. Appl. Surf. Sci. 2021, 563, 150221. [CrossRef]

20. He, Q.; Zhang, H.; Li, J.; Duan, H. Performance evaluation of polyurethane/epoxy resin modified asphalt as adhesive layer material for steel-UHPC composite bridge deck pavements. Constr. Build. Mater. 2021, 291, 123364. [CrossRef]

21. Zhou, X.; Hai, Z.; Tong, Y. The diseases analysis of steel bridge deck pavement of Epoxy Asphalt Concrete. Highw. Traffic Sci. Technol. 2010, 26, 105-107.

22. Yu, S.; Ou, J. Fatigue life prediction for orthotropic steel deck details with a nonlinear accumulative damage model under pavement temperature and traffic loading. Eng. Fail. Anal. 2021, 126, 105366. [CrossRef]

23. Wang, Z.; Zhang, S. Fatigue endurance limit of epoxy asphalt concrete pavement on the deck of long-span steel bridge. Int. J. Pavement Res. Technol. 2018, 11, 408-415. [CrossRef]

24. Zhang, H.; Mao, Q.; Zhu, Z.; Zhang, Z.; Pan, Y.; Wan, J.; Zhou, C.; Qian, J. Experimental study on service performance of epoxy asphalt steel deck pavement of cable stayed bridge. Case Stud. Constr. Mater. 2020, 13, e00392. [CrossRef]

25. Liu, C.; Qian, Z.; Liao, Y.; Ren, H. A Comprehensive Life-Cycle Cost Analysis Approach Developed for Steel Bridge Deck Pavement Schemes. Coatings 2021, 11, 565. [CrossRef]

26. Fan, X.; Luo, R. Experimental study on crack resistance of typical steel-bridge-deck paving materials. Constr. Build. Mater. 2021, 277, 122315. [CrossRef]

27. Olard, F.; Héritier, B.; Loup, F.; Kraft, S. New French Standard Test Method for the Design of Surfacings on Steel Deck Bridges Case Study of the Millau Viaduct. Road Mater. Pavement Des. 2005, 6, 515-531. [CrossRef]

28. Xiang, D.; Gu, M.; Zou, X.; Liu, Y. Fatigue behavior and failure mechanism of steel-concrete composite deck slabs with perforated ribs. Eng. Struct. 2021, 250, 113410. [CrossRef]

29. Yu, H.; Zhu, Z.; Leng, Z.; Wu, C.; Zhang, Z.; Wang, D.; Oeser, M. Effect of mixing sequence on asphalt mixtures containing waste tire rubber and warm mix surfactants. J. Clean. Prod. 2019, 246, 119008. [CrossRef]

30. Yu, H.; Leng, Z.; Dong, Z.; Tan, Z.; Guo, F.; Yan, J. Workability and mechanical property characterization of asphalt rubber mixtures modified with various warm mix asphalt additives. Constr. Build. Mater. 2018, 175, 392-401. [CrossRef]

31. Zhang, J.; Huang, W.; Hao, G.; Yan, C.; Lv, Q.; Cai, Q. Evaluation of open-grade friction course (OGFC) mixtures with high content SBS polymer modified asphalt. Constr. Build. Mater. 2020, 270, 121374. [CrossRef]

32. Zhang, S.; Wang, D.; Guo, F.; Deng, Y.; Feng, F.; Wu, Q.; Chen, Z.; Li, Y. Properties investigation of the SBS modified asphalt with a compound warm mix asphalt (WMA) fashion using the chemical additive and foaming procedure. J. Clean. Prod. 2021, 319, 128789. [CrossRef]

33. Xu, C.; Wang, D.; Zhang, S.; Guo, E.; Luo, H.; Zhang, Z.; Yu, H. Effect of Lignin Modifier on Engineering Performance of Bituminous Binder and Mixture. Polymers 2021, 13, 1083. [CrossRef] [PubMed]

34. Wu, H.; Huang, K.; Song, W.; He, F. Characterizing the fatigue cracking behaviors of OGFC pavements using the overlay tester. Constr. Build. Mater. 2021, 307, 124979. [CrossRef]

35. AASHTO GDHS-4; Pavement Structure Design Guide. American Association of State Highway and Transportation Officials: Washington, DC, USA, 1993. 